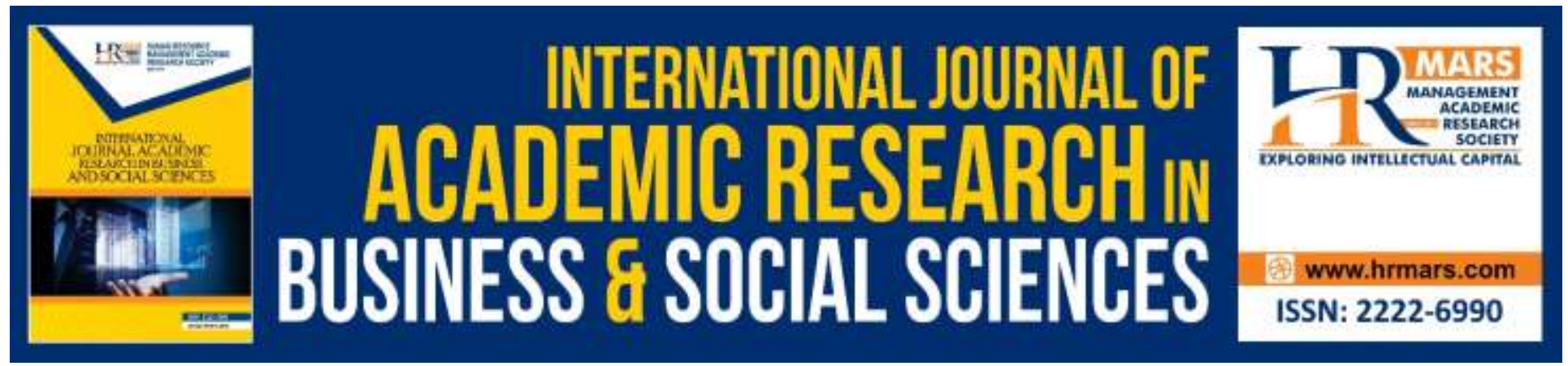

\title{
The Awareness of Zakat in the Universal Society
}

\author{
Nur Salma Sabrina Binti Sahaluddin, Wan Khairul Aiman Wan Mokhtar
}

To Link this Article: http://dx.doi.org/10.6007/IJARBSS/v9-i11/6586 DOI: 10.6007/IJARBSS/v9-i11/6586

Received: 02 October 2019, Revised: 21 October 2019, Accepted: 06 November 2019

Published Online: 23 November 2019

In-Text Citation: (Ling et al, 2019)

To Cite this Article: Sahaluddin, N. S. S. B., Mokhtar, W. K. A. W. (2019). The Awareness of Zakat in the Universal Society . International Journal of Academic Research in Business and Social Sciences, 9(11), 647-651.

Copyright: (C) 2019 The Author(s)

Published by Human Resource Management Academic Research Society (www.hrmars.com)

This article is published under the Creative Commons Attribution (CC BY 4.0) license. Anyone may reproduce, distribute, translate and create derivative works of this article (for both commercial and non-commercial purposes), subject to full attribution to the original publication and authors. The full terms of this license may be seen at: http://creativecommons.org/licences/by/4.0/legalcode

Vol. 9, No. 11, 2019, Pg. 647 - 651

http://hrmars.com/index.php/pages/detail/IJARBSS

JOURNAL HOMEPAGE

Full Terms \& Conditions of access and use can be found at http://hrmars.com/index.php/pages/detail/publication-ethics 


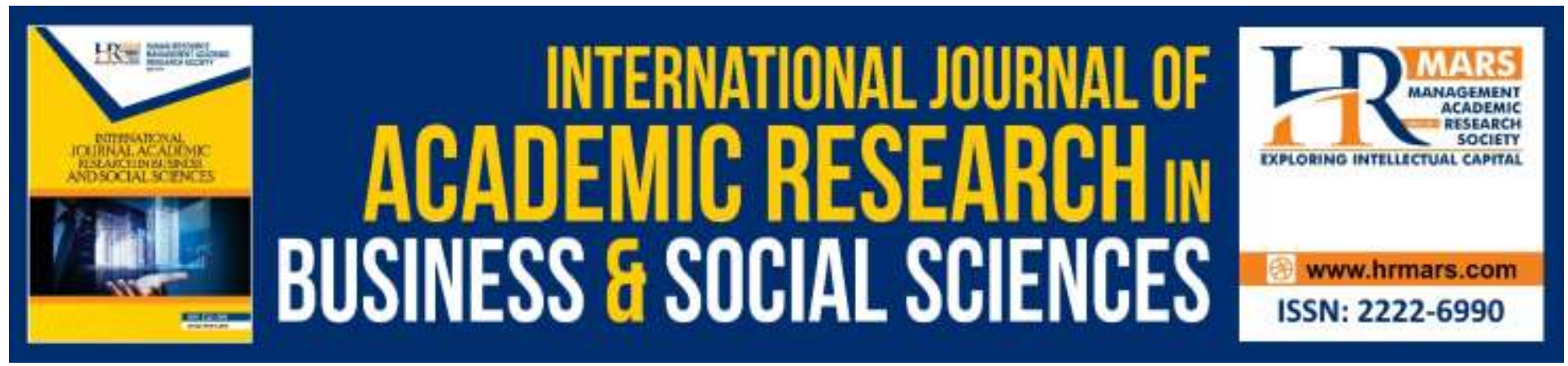

\title{
The Awareness of Zakat in the Universal Society
}

\author{
Nur Salma Sabrina binti Sahaluddin, Wan Khairul Aiman Wan \\ Mokhtar \\ Universiti Sultan Zainal Abidin (UniSZA), Gong Badak Campus, 21300, Kuala Nerus, Terengganu, \\ Malaysia
}

\begin{abstract}
Zakat is the name or designation of a right issued by a god to those who deserve it. It is called zakat as it contains the hope of blessing, cleansing the soul and nurturing it with all sorts of virtues. The problem is, why is there still a handful of Muslims who have not yet fulfilled this claim? What steps that should be taken by the zakat institutions for raise this awareness? What is the factor that determines it to give awareness to every Muslim? Therefore, this study aimed to bring awareness to all Muslims to pay zakat and how important is to identify the real concept of charity and a great role in the global community. This study uses qualitative methods that refer to books, articles, scientific journals and reports from the State Islamic Religious Council. The findings have found that some factors such as age, marital status and income are a major significant which may influence the payment of zakat as well as zakat payment mechanism through salary deductions. There are several policy implications have also been proposed to recover the zakat institutions to advance the performance of zakat in Malaysia.
\end{abstract}

Keyword: Zakat, Awareness, State Islamic Religious Council

\section{Introduction}

As a Muslim, we must perform our obligations by paying zakat just as we are obliged to perform the prayers so we will become a perfect Islam in the eyes of Allah and the universal society. Zakat has a very high position in Islam and his words always be combined with a prayer in the Quran. Zakat is also worship that has a high social value. The role of zakat is to reduce the poverty of local communities. Zakat must be removed for certain types of property that has been set after the qualifying period. Obligations of zakat have a variety of positive socio-economic objectives not only to the recipient of zakat but also to zakat payers and to the whole society.

Generally, charity to further strengthen the social security system and it is also the first step that should be addressed properly and smoothly towards the Islamic economic system toward a more perfect. (Alkhatib, Abdul-Jabbar, Munusamy Marimuthu, 2018; Terzidis, 2018) 
In fact, it was stated in the Quran that charity is part of the characteristics of those who believe as Allah says:

Means:"And those who believe, men and women, in part as allies of one another, they enjoin good and forbid evil, they observe regular prayers, practice regular charity, and obey Allah and His Messenger Muhammad. They will be blessed by Allah SWT, Surely Allah SWT is Powerful Wise."

Surah At-Taubah (9): 71

As for those who failed to perform the obligation of zakat has been promised a painful punishment in the hereafter. This is confirmed as the word of Allah SWT:

Means: "Say (Muhammad): I am only a mortal just like you; it is revealed to me that your God is One God; then be firm on the straight path (leading to attain His Pleasure), and ask Him to forgive (sins of the past). And remember, woe to those who associate him (with something else), to those who do not pay zakat (to cleanse the soul and wealth) and who are disbelievers in the Hereafter."

Surah Al-Fussilat (41): 6 \& 7

In addition, the question is why there are still some Muslims who still have not paid zakat. So to explain in detail that there is an order to pay the obligatory submission contained in the Koran to Islamic institutions or charities to pick it up for those who refuse to do so.

Allah swt says in the Quran (Al-Taubah 9: 103) which means "Take their property sadaqah (zakat) to purify and purify them with it". Any property that zakat must be clearly stated on the hadith of the Messenger of Allah must be obeyed without reason. Denies the obligation of zakat is an infidel (Al-Syaukani 1973: 170).

The accumulation of zakat can ensure the high social security aspect of Muslims increases. Due to a problem in the awareness of the importance of paying zakat then there is some obligation to implement the charity claims from the point of view of jurisprudence is still in deviation angle and of course there are a few responses, perceptions and different reactions among the people regarding obedience to pay it.

Normally, discussions about this research are to examine the public's consciousness of paying zakat and ultimately suggesting some basic implications is to raise awareness.

\section{Research Methodology}

Research methodology is important to produce a study. Without any methodology, this study cannot be used as a study to make reference and applied in any field. To achieve the objectives of this study, this study was conducted in accordance with the research methodology (Mokhtar, 2017).

This study was conducted with a qualitative approach. For the data collection, data are collected from libraries, journals, books, and website of charity institutions in Malaysia as well as other websites related to charity or zakah. From the collecting data, the data was analysed. A conclusion is made after the data is analyzed. (Mokhtar, 2017; Rabi, Ghazali, Rohaizad, \& Zulkefli, 2018). 


\section{Findings and Research Discussion}

For the purpose of creating awareness about charity, there are some laws for those who refused to pay zakat. This is because zakat is an obligation in Islam and it is informed by every Muslim. Those who are refused or disobeyed about his duties meant he was out from the religion of Islam and punishable by the death in a state of disbelief. But if the refusal is due to the ignorance of some Islamic laws then it may be excluded.

This is especially for those who do not pay the zakat but still admits that he is guilty and must therefore not come from Islam. In this case, the judge who is the head of state must take it by force zakat and sentenced ta'zir. Allah has promised the doom to those who do not want to pay zakat by His word:

"And those who store gold and silver and do not spend it in the way of Allah, then tell them, that they will get a painful torture. On the Day when they are heated in hell, they will burn with their

foreheads, their hindrances and their backs (to them): 'This is the property which you have stored for yourselves, so taste now what you save it."

Surah At-Taubah (9): 34-35

The zakat property that is to be collected must be distributed to the beneficiaries of 8 asnaf as stated in the Quran:

Which means:

"Verily the charity is only for the poor, the poor and the practicing amil and the tamed muallaf and the slaves who want to liberate themselves, and those who are indebted to spend in the way of Allah and the traveler (the decision of money) on the way. A lawful provision that comes from Allah SWT, and indeed Allah SWT is Most Knowing of the Most Wise".

Surah At-Taubah (9): 60

\section{Conclusion}

In conclusion, raising the awareness of paying zakat income is very important. This is because as it is one of the mandatory things and is one of the five pillars of Islam then it should be emphasized. Although individual income has been classified as figh as a zakat property, in Malaysia the obligatory income of this zakat comes with the declaration of fatwa Muzakarah of the National Fatwa Council Committee in 1997. However, it should be understood here that the charity has socio-economic benefits are the same as alms. In fact, if the collection of charity is increasing, the money that can be distributed also is increasing. Therefore, it can also help a lot of recipients especially for those who are poor and needy recipients in their daily lives. An enormous collection of zakat in a certain countries is a contribution donated by the accumulation of zakat earnings. These improvements will ultimately be able to create a society of mutual apprehension, especially for Muslim households experiencing poverty can be gradually abolished. Therefore, the zakat institutions need to improve the campaign and talks to ensure that the Muslim civic in Malaysia can distinguishes the significance of zakat payment and know 
the goals and philosophy behind zakat. The public perception of Islam's charity institutions also needs to be improved through increased management efficiency zakat.

\section{Acknowledgement}

This paper is founded on the research project of the Fundamental Research Grant Scheme FRGS/1/2018/SSI03/UNISZA/02/2 (Project No: RR279). Special appreciation is owed to Ministry of Higher Education Malaysia (MOHE) and Universiti Sultan Zainal Abidin (UniSZA) for sponsoring and supporting this research.

\section{Corresponding Author}

Wan Khairul Aiman bin Wan Mokhtar (Ph.D), Senior Lecturer, Universiti Sultan Zainal Abidin (UniSZA), Kampus Gong Badak, 21300 Kuala Nerus.

E-mail: wk_aiman@yahoo.com / wkhairulaiman@unisza.edu.my

\section{References}

Alkhatib, A. A., Abdul-Jabbar, H., Marimuthu, M. (2018). The Effects of Deterrence Factors on Income Tax Evasion among Palestinian SMEs, International Journal of Academic Research in Accounting, Finance and Management Sciences 8 (4): 144-152.

Mokhtar, W. K. A. W. (2017). Concept Al-Hadīth Al-Mawḍu'iy as a Method of Collecting and Analyzing Research's Data. International Journal of Academic Research in Business and Social Sciences, 7(2), 2222-6990.

Omar, M., Kamaruddin, N. \& Sungip, F. (2016). Konsep Zakat dan Peranannya Terhadap Masyarakat Sejagat.

Rabi, N. M., Ghazali, N. H. C. M., Rohaizad, N. A. A., \& Zulkefli, M. Y. (2018). Readiness of PreService Teacher to teach Student with Special Needs through Inclusive Education Course. International Journal of Academic Research in Progressive Education and Development, 7(4), 200-210.

Terzidis, E. (2018). Stress in Primary School Principals of Pella Regional Unit. Multilingual Academic Journal of Education and Social Sciences, 6(1), 182-198 (in Greek).

Wahid, H., Ahmad, S. \& Noor, M. A. M. (2007). Kesedaran Membayar Zakat Pendapatan di Malaysia.

Wahid, H., Ahmad, S., \& Noor, M. A. M. (2005). Kesedaran Membayar Zakat: Apakah Faktor Penentunya. 